\title{
Public Finance, Governance, and Cash Transfers in Alleviating Poverty and Inequality in Chile
}

\author{
Claudio A. Agostini ${ }^{1}$ \\ Philip H. Brown ${ }^{2}$ \\ Diana Paola Góngora ${ }^{3}$
}

November 2008

\begin{abstract}
As the Chilean government seeks to reduce both poverty and inequality through cash transfers to poor households, local governments are responsible for both identifying the poor and allocating transfers. Until recently, however, evaluating the effectiveness of local governments in enacting these policies has been restricted by data limitations. The paper builds on recent evidence that cash transfers had highly variable impacts on poverty and inequality at the county level in 2002. In particular, we explore how local public finance and the strength of the governing mandate influence the efficiency of cash transfers. With a richly-specified model, we find that public spending on goods and services, the fraction of available subsidies claimed by the local government, and the share of county land that is zoned for industrial purposes are all correlated with considerable reductions in poverty and inequality. In addition, the strength of the governing mandate weakly influences the efficiency of transfers in reducing poverty, but not inequality. These results demonstrate that a better understanding of such institutions can lead to more efficient targeting for social programs.
\end{abstract}

Keywords: Monetary transfers; Inequality; Poverty

JEL Classification: H53, I32, O15

\footnotetext{
${ }^{1}$ Ilades-Universidad Alberto Hurtado, Santiago, Chile. Email:agostini@uahurtado.cl

${ }^{2}$ Colby College, Waterville, Maine, USA. Email:phbrown@colby.edu (corresponding author)

${ }^{3}$ Fiscalía Nacional Económica, Santiago, Chile. Email:dpaolagongora@gmail.com
} 


\section{Introduction}

Many countries in Latin America have seen dramatic reductions in poverty in recent decades, with the headcount ratio falling below $30 \%$ in Argentina and Uruguay and below $20 \%$ in Chile, Costa Rica, and Mexico by 2008 (Table 1). Chile now exhibits the lowest poverty rates in the region at $13.7 \%$. Income inequality, by contrast, remains high across the entire region, with Gini indices for 2006 ranging from 0.43 in Nicaragua to 0.59 in Bolivia. Despite success in combating poverty, Chile's Gini index of 0.54 remains high, even within this comparison group of countries with high income inequalities.

While Chile's success in poverty reduction is largely due to the positive effects of economic growth, various social programs that consist of targeted transfers, both cash and inkind, have also played an important role (Pizzolito 2005; Contreras 1996, 2001). Although transfers provided by the government were initially intended to address poverty, current efforts are focused on addressing inequality as well. Specifically, the government has proposed programs to strengthen local governance ${ }^{1}$ in general and to increase their efficiency in allocating cash transfers for the purposes of reducing poverty and inequality in particular (Presidential Address 2008).

Identifying the characteristics of local governments that make them more or less effective in allocating cash transfers for the purposes of reducing poverty and inequality is central to meeting these objectives. Despite the fact that transfers are mainly targeted at the level of provinces, survey data with detailed income measures are not representative at this level.

\footnotetext{
${ }^{1}$ Chile is comprised of 13 administrative regions. Each has a formal name and a Roman numeral, the latter more commonly used. The numbers are assigned sequentially from north to south, with the exception of Region XIII (the Santiago Metropolitan Region), which is located between Regions V and VI. Each region consists of multiple provinces, which are further divided into counties. Each county has its own government except Antártica, which is governed by Cabo de Hornos County. We focus on the 341 independent counties. In 2004, four counties were divided, bringing the number of counties up to 346 .
} 
Therefore, the impact of public policy is generally evaluated at the regional level (e.g. Contreras and Ruiz-Tagle 1997; Contreras 2001; Pizzolito 2005). Two exceptions are Agostini and Brown (2007a, 2007b), which combine census data with survey data to develop statistically-precise estimates of poverty and inequality at the county level using poverty mapping methods (Elbers, Lanjouw, and Lanjouw 2003). ${ }^{2}$ The authors demonstrate considerable heterogeneity among counties in terms of how cash transfers impact poverty and inequality. Given the current government's objective of reducing poverty and inequality by increasing the resources available to local governments, a better understanding of this heterogeneity is thus of great policy significance.

The goal of this paper is to employ the county-level estimates developed by Agostini and Brown (2007a, 2007b) to analyze how variation in public finance and the strength of the local mayor's governing mandate impact the effectiveness of cash transfers in reducing poverty and inequality at the local level within the context of a rich set of controls. We find that characteristics of the local public finance regime such as spending on goods and services, the fraction of water subsidies made available by the regional government claimed by the local government, and the share of county land that is zoned for industrial purposes are associated with greater reductions in inequality and poverty stemming from cash transfers. The strength of the governing mandate also increases the efficacy of cash transfers in reducing poverty, although this effect in not quite significant at conventional levels.

The rest of the paper is organized as follows: Section 2 describes the implementation of poverty mapping analysis and the institutional context of cash transfers in Chile; Section 3 provides an overview of the variables associated with poverty rates and the distribution of

\footnotetext{
${ }^{2}$ Census data are representative by definition, yet they do not include detailed information on income. Survey data, by contrast, do include information on income, but they are not representative below the regional level.
} 
income across countries and regions; Section 4 presents the empirical specification and analysis which identify the characteristics associated with efficient cash transfers in Chile; and Section 5 concludes.

\section{Cash Transfers and Local Governments}

Due to limitations inherent in survey data, most studies that examine poverty and inequality do so at highly aggregated levels such as countries or states/regions/provinces. However, newly developed methods allow such welfare indicators to be estimated at more disaggregated levels, e.g., counties and provinces. One of the main advantages of considering poverty and inequality at disaggregated levels is that it captures heterogeneity across different areas within a country; such heterogeneity is a major factor for consideration when it comes to the allocation of public resources. For example, Demombynes et al. (2004) and Elbers et al. (2004) suggest that addressing heterogeneity across regions can improve the targeting and impact of resource allocation.

In the absence of survey data that are statically-representative at low levels of aggregation, poverty mapping has emerged as a popular tool for estimating poverty and inequality at the local level. Although the data and computational needs for poverty mapping are considerable, there are several important advantages to using poverty maps relative to relying on aggregate estimates of poverty and inequality in formulating public policy. First, Baker and Grosh (1994) show that poverty maps increase the effectiveness of targeting in allocating resources to poverty-stricken areas. Poverty maps also enhance targeting by focusing on smaller geographic areas wherein income variation is likely to be smaller than that at the state, regional, or country level (Bigman and Fofack 2000). Further, Hyman, Larrea, and Farrow (2005) show 
that poverty mapping may be used to help identify the relative importance of various correlates of poverty and inequality.

The most sophisticated poverty maps combine survey and census data to develop statistically-reliable estimates of poverty and inequality at the local level. For example, Agostini and Brown (2007a, 2007b) use the methods described by Elbers et al. (2003) to estimate the impact of cash transfers provided by the government on the levels of poverty and inequality in Chilean counties. While the empirical results show that transfers have a significant impact on reducing poverty and inequality at the local level, there is tremendous heterogeneity across regions, suggesting that measures such as public finance regimes and/or the political will of their governments may influence these outcomes (e.g., Simpson 1990; Chong and Caderón 2000; Mahler 2002; Brady 2003).

In particular, local governments play a central role in implementing many social programs in Chile. ${ }^{3}$ The targeting mechanism in almost all of the programs is the "CAS-2 Card," which gathers data on household demographics, employment and income, the ownership of various durable goods and assets, the physical quality of housing, and access to potable water to determine eligibility and priority for transfers for poverty relief. ${ }^{4}$ Since each household is evaluated at the request of its head, poor households that do not request a CAS-2 Card evaluation are ineligible to receive transfers. As the government in each county is responsible for promoting and administering the CAS-2 Card, varying degrees of efficiency across localities may affect the impact of cash transfers on poverty and inequality at the local level.

\footnotetext{
${ }^{3}$ The role of local governments in allocating social expenditures has increased dramatically since Scarpaci and Irrarazaval (1994) observed that virtually all authority for financial decision making rests with the central authorities.

${ }^{4}$ Soto and Torche (2004) provide additional details on the CAS-2 Card and the classification of poor households.
} 
To identify the effects of public finance and governance on the efficiency of cash transfers, it is important to control for other determinants of poverty and inequality. The literature provides ample evidence that poverty and inequality are strongly influenced by access to economic opportunities as exemplified by transportation networks (e.g., Kanbur and Zhang 2005), levels of education (e.g., Lenski 1966; Nielsen and Anderson 1995; Haimovich, Winkler and Gasparini 2006), and the share of county residents that lives in urban areas (e.g., Greenwood and Jovanovic 1990; Wratten 1995; von Braun 2007). Further, infrastructure development may play an important role in poverty and inequality more generally (e.g., Gustafsson and Johansson 1999; Bourguignon and Chakravarty 2003). Socio-demographic characteristics of the local area may also influence local levels of poverty and inequality, including the gender of household heads (e.g., Eberharter 2001; Gustafsson, Li, and Sicular 2008) and the share of elderly people in the population (e.g., Jones 2007; Gustafsson et al 2008). Finally, there is an interrelationship between poverty and inequality (e.g., Barro 1999; Gustafsson and Johansson 1999; Ravallion 2005) that may correlate with public finance and governance.

In this study, we evaluate the extent to which four different measures of local public finance and one measure of political governance influence the impact of cash transfers on poverty and inequality at the local level using the county-level figures derived by Agostini and Brown (2007a, 2007b). In particular, we consider the effects of current expenditures on goods and services (as a share of total current expenditures), the ratio of expenditures to income, the share of water subsidies authorized by the regional government and claimed by the county government, and the share of county land zoned for industrial purposes as measures of local public finance. 
The fraction of county expenses allocated to running the bureaucracy is perhaps the best measure of local public finance as budgetary decisions are generally under the direct control of county administrators (Chubb and Moe 1990). Unfortunately, we cannot include this measure directly due to a lack of data reporting in many Chilean counties. However, given that the bulk of current expenditures in Chilean counties are allocated either to good and services or to bureaucracy, the fraction allocated to the former essentially serves as a proxy for the latter (or its inverse, at least). ${ }^{5}$ Therefore, spending on goods and services as a share of total spending captures is our first measure to capture the potential complementarity of local public goods and cash transfers in reducing poverty. The second measure is the expenditure/revenue ratio, which captures the ability of local governments to finance their own spending; this inverse of this measure reflects investment, which may impact future reductions of poverty and inequality. ${ }^{6}$ Our third measure of local public finance is the share of the total number of water subsidies (one of five transfer programs intended to alleviate poverty in Chile) authorized by the regional government that is claimed by the local government. This measure captures efficiency in identifying poor households for poverty alleviation, and perhaps concern for poverty and inequality more generally. The final measure of local public finance is the share of county land that is zoned for industrial purposes. This variable captures local government efforts to use regulatory instruments to generate employment and income by facilitating relocation of industrial firms to the county.

To model the strength of the governing mandate, we interact the share of votes won by the local mayor with a dummy that indicates whether he or she belonged to the Concertación de

\footnotetext{
${ }^{5}$ In counties for which both measures are available, the simple correlation is -0.91 .

${ }^{6}$ Examples of this include investment in education and in infrastructure.
} 
Partidos por la Democracia, a coalition of center-left parties. ${ }^{7}$ Every Chilean president elected since the end of military rule in 1990 has been a member of the coalition, indicating that mayors elected under its banner are likely to have strong mandates. Moreover, mayors who won by greater margins are more likely to enjoy popular support to enact legislation on behalf of their constituents, particularly the redistribution of wealth (Acemoglu and Robinson 2002). Both interpretations are consistent with Van Der Rijt's (2008) notion of altruistic governing coalitions.

Thus, for inequality, we estimate:

$$
\Delta \% G_{i}=\beta_{0}+\beta_{1} \mathbf{P} \mathbf{F}_{i}+\beta_{2} G_{i}+\beta_{3} \mathbf{C}_{i}+\sum_{j=1}^{12} \alpha_{j} \mathbf{R}_{j}+\varepsilon_{i}
$$

Here $\Delta \% G_{i}$ is the percentage change in the Gini index associated with cash transfers in county $i$, PF is the vector of variables describing public finances noted above; $G$ is the measure of the strength of the governing mandate described above, $\mathbf{C}$ is a vector of controls that describe important characteristics of the county and the socio-demographics of the people residing there, and $\mathbf{R}$ is a vector of interaction terms between regional dummies and the share of county residents living in urban areas to capture the impact of unobserved heterogeneity at the regional level. $^{8}$

Because poverty lines differ in rural and urban areas, the determinants of rural and urban poverty are estimated in two different equations using a Seemingly Unrelated Regression framework:

\footnotetext{
${ }^{7}$ Member parties include the Christian Democrat Party, the Party for Democracy, the Socialist Party, and the Social Democrat Radical party.

${ }^{8}$ Ideally, this regression would include a county fixed effect. In the absence of panel data, however, we use the region * urban share interactions instead.
} 


$$
\begin{aligned}
& \Delta \% H_{\text {Rural }, i}=\beta_{0}+\beta_{1} \mathbf{P F}_{i}+\beta_{2} G_{i}+\beta_{3} \mathbf{C}_{i}+\sum_{j=1}^{12} \alpha_{j} \mathbf{R}_{j}+\varepsilon_{1 i} \\
& \Delta \% H_{\text {Urban }, i}=\beta_{0}+\beta_{1} \mathbf{P F}_{i}+\beta_{2} G_{i}+\beta_{3} \mathbf{C}_{i}+\sum_{j=1}^{12} \alpha_{j} \mathbf{R}_{j}+\varepsilon_{2 i}
\end{aligned}
$$

Here $\Delta \% H_{i}$ is the percentage change in the headcount ratio in county $i$ as a result of the impact of cash transfers. The Seemingly Unrelated Regression approach allows for errors to be correlated across equations, and by estimating the equations jointly, efficiency is improved relative to Ordinary Least Squares (Zellner 1962).

\section{Data}

The changes in the county-level Gini indices and headcount ratios used in this study are based on 2002/2003 estimates reported in Agostini and Brown (2007a, 2007b). ${ }^{9}$ Table 4 presents descriptive statistics of each of these measures by region. Nationwide, cash transfers spurred a $7.7 \%$ reduction in county-level Gini indices and a $13.5 \%$ reduction in headcount ratios. Poverty reduction was much more dramatic in rural areas than in urban areas. There is a significant degree of heterogeneity across regions, however, confirming the importance of controlling for unobservable regional characteristics in our analysis. ${ }^{10}$

As described in Section 2, the influence of public finance on the efficiency of cash transfers in reducing poverty and inequality are measured by current expenditures on goods and services (as a share of total current expenditures), the ratio of expenditures to revenues, the share of water subsidies authorized by the regional government that was claimed by the county government, and the share of county land zoned for industrial purposes. These data are derived

\footnotetext{
${ }^{9}$ Their estimates are based on applying the method described in Elbers et al. (2003) to the 2002 census and the 2003 Encuesta de Caracterización Socioeconómica (CASEN).

| ${ }^{10}$ The standard deviation in the percentage change of Gini indices among regions is 3.5\% while that for the headcount ratios is $4.7 \%$. The standard deviation in the percentage change of rural and urban headcount ratios are $6.1 \%$ and $1.7 \%$, respectively.
} 
from SINIM, a database of municipal management of the Undersecretary of Regional Development and Administration at the Ministry of the Interior. Since 2001, the system has collected data pertaining to administration and finance, health, education, land management, and other characteristics of each of Chile's counties with the twin goals of providing data to facilitate the decision-making process and to enhance the management of public institutions.

The strength of the local government's political mandate, as measured by the percentage of votes won by the mayor interacted with a dummy that indicates whether he or she belongs to a party in Chile's governing coalition, is obtained from the Electoral Service. The Electoral Service is the authority in charge of administering Chile's electoral system and keeping all election records.

Several county-level characteristics that will serve as control variables, including ease of access to the regional capital, the average level of schooling among adults in the county, and the share of the county population residing in urban areas, are also drawn from the SINIM. The share of households connected to the public water supply is derived from the census conducted by the National Institute of Statistics on April 24, 2002. The census covered 4,112,838 households composed of $15,545,921$ individuals. The census is also the source of data for sociodemographic controls such as the share of households with female heads and the share of elderly people in the county population.

Table 5 presents descriptive statistics for the explanatory variables identified in the preceding paragraphs; complete data are available for 327 counties. Public expenditures on goods and services in the community represent $18 \%$ of total expenditures, on average. These expenditures include spending on utilities, maintenance and groundskeeping in public spaces, security services, research, training courses, public kindergarten programs, and similar programs. 
There is considerable variation in this allocation across counties, with one county allocating $48 \%$ of its expenditures to such items. Expenditures represent $83 \%$ of revenues on average, although expenditures exceed revenues in several counties, by margins as high as $20 \%$. The fraction of subsidies claimed is measured by the total number of water subsidies given by the county divided by the total number that is authorized (and hence funded) by the regional authorities. That is, this measure captures how well counties are able to identify beneficiaries of resources that have been allocated to them. On average, counties allocate $79 \%$ of the subsidies authorized by the regional governments, although this figure exceeds $95 \%$ in many counties. Areas zoned for industrial purposes represent $8 \%$ of the total land in the average county, although the high standard deviation indicates considerable variation in this measure. As noted above, the strength of the governing mandate is measured by the percentage of votes won by the mayor interacted with a dummy that indicates whether he or she belongs to the governing coalition of center-left parties.

Three variables indicate access to economic opportunities - ease of access to the regional capital, average education, and urban population. The first variable is a dummy that takes a value of 1 if the capital is accessible via sealed roads year round and 0 otherwise. Some $82 \%$ of counties have year-round access to the regional capitals via sealed roads. The adult population averages seven years of education and $61 \%$ of the population lives in urban areas. The share of county residents that requested evaluations to determine and prioritize their eligibility for poverty alleviation, i.e., those who requested a CAS-2 Card assessment, averaged 52\%. However, no households applied in one county while virtually every household applied in several others, suggesting that poverty varies widely by county and that the program has not been promoted equally across counties. On average, $76 \%$ of households had access to drinking water through 
public infrastructure. Finally, $28 \%$ of households in the average county are headed by women and $9 \%$ of the population in the average county was older than 65 .

\section{Results}

\subsection{Inequality}

Table 4 shows the influence of public finance, the strength of the governing mandate, and county and socio-demographic characteristics on county-level reductions in inequality stemming from transfers provided by the regional government, as specified in Equation (1). The first column is the basic specification. The second column adds the headcount ratio of each county before cash transfers as an additional regressor to account for the empirical regularity that poverty levels influence inequality and vice versa (Barro 1999; Gustafsson and Johansson 1999; Ravallion 2005). The third column then adds an additional term to capture the strength of the local mayor's political mandate. Interaction terms describing the region and the share of the county population residing in urban areas are included in all three specifications to control for unobserved heterogeneity. The results of the three specifications are similar, and variation in the regressors jointly explains $83 \%$ of the variation in the effectiveness of cash transfers in reducing inequality at the county level.

Each of the four measures of public finance influences local inequality. Specifically, a 1percentage point increase in the ratio of government spending on goods and services to total spending implies a $2.6 \%$ reduction in the county-level Gini index, significant at the $90 \%$ confidence level in the last specification. Government efficiency (as measured by the share of water subsidies authorized by the regional government claimed by the local government) also impacts inequality: a 1-percentage point increase in efficiency reduces the estimated Gini index by an additional $2.6 \%$, significant at the $99 \%$ confidence level in all three specifications. 
Similarly, a 1-percentage point increase in the share of land that is zoned for industrial purposes is associated with a $1.6 \%$ greater reduction in the Gini index, again significant at the $99 \%$ confidence level. By contrast, higher expenditure/revenue ratios are associated with smaller reductions in inequality, suggesting that poorer counties are less effective in targeting inequality via cash transfers. ${ }^{11}$

Although statistics on income at the county-level are unavailable from official sources, including county and socio-demographic characteristics such as the ease of access, the average education among county residents, the share of residents living in urban areas, the percentage of households with public water supply, and the share of households headed by women in the model allows us to indirectly control for economic opportunity and the level of economic development in each county. ${ }^{12}$ We find that good transportation connectivity to the regional capital reduces the effectiveness of transfers in combating inequality, perhaps because good roads disproportionately facilitate access to high-paying jobs in the regional capital for people with their own means of transportation. Average education in the county also negatively impacts the effectiveness of transfers in reducing inequality, suggesting that education inhibits targeting, perhaps because more educated people have better access to non-local labor markets. A higher share of the county population residing in urban areas is also associated with lower effectiveness in using transfers to combat inequality in the wealthiest regions (i.e., Regions II, V, XII, and XIII) but a higher effectiveness in Regions VII, VIII, IX, X, and XI. Increases in the proportion

\footnotetext{
${ }^{11}$ All of these patterns and results hold when also controlling for the initial level of inequality, suggesting that they are rather robust.

${ }^{12}$ Given limited degrees of freedom and the high potential for multicollinearity among some county and sociodemographic characteristics, it is impractical to include all of controls described in Table 5 in the regressions. We thus restrict the analysis to the subset of controls that maximize the predictive power of the model and to those that are interesting from a theoretical perspective.
} 
of households with public water access and with female heads are associated with lower effectiveness in combating inequality via transfers. ${ }^{13}$

Interestingly, the point estimate on the share of county residents that requested poverty assistance from the government (the basic precursor to becoming eligible) is negative as anticipated, suggesting that higher eligibility leads to greater reductions in inequality via transfers, although this effect is not statistically significant. Similarly, the poverty rate included in Model (2) is correlated with a greater impact of transfers on inequality, although the effect is also not statistically significant at conventional levels. Finally, the strength of the governing mandate is correlated with smaller reductions in inequality (Model 3), although the relationship is not statistically significant. Ceteris paribus, this result suggests that politically-powerful leaders are no more effective in reducing inequality than those whose parties are outside the governing coalition and those who won the election by slim margins.

\subsection{Poverty}

As in many countries, Chile's official poverty line for rural residents is below that for urban residents. Because the nature of poverty and effective targeting practices may differ for these two groups, we analyze the determinants of reductions in headcount ratios associated with cash transfers separately for rural and urban residents (Equation 2). As noted above, however, we use Seemingly Unrelated Regression techniques to improve the efficiency of the estimates.

There are 28 counties in which all residents are classified as being urban and 26 counties in which all residents are classified as being rural (Appendix 1). As such, the number of data

\footnotetext{
${ }^{13}$ To verify the robustness of the results against the omission of county-level income in the regression, Equation (1) was re-estimated with average income per capita in each county as estimated by Agostini and Brown (2007a). The results do not change appreciably.
} 
points in the poverty analysis falls by approximately $9 \%$ relative to the inequality analysis. Interaction terms describing the region and the share of the county population residing in urban areas are included in all specifications. The regressors have very high explanatory power for cross-sectional data (Table 5): variation in public finance, the strength of the governing mandate, and county and socio-demographic characteristics account for between $77 \%$ and $80 \%$ of the total variation in poverty reduction after cash transfers.

The influence of public finance on poverty reduction is similar to that for inequality reduction. Specifically, a 1-percentage point increase in the ratio of government spending on goods and services to total spending is associated with a $4.3 \%$ greater reduction in poverty in rural areas (significant at the $95 \%$ confidence level) and a $1.3 \%$ greater reduction in urban areas (significant at the $90 \%$ confidence level). Similarly, a 1-percentage point increase in the share of land in the county zoned for industrial purposes leads to a $12.3 \%$ larger reduction in poverty in rural areas (significant at the $99 \%$ confidence level) ${ }^{14}$ although the effect is not distinguishable from zero in urban areas. The expenditure/revenue ratio is weakly correlated with smaller reductions poverty rates resulting from cash transfers in rural areas, although this effect is not statistically significant.

County and socio-demographic characteristics included in the regression include ease of access, the share of county residents living in urban areas, and the share of elderly people in the county population. ${ }^{15}$ Ease of access is associated with smaller reductions in poverty rates for urban residents, suggesting that members of households with better transportation options are harder to target, perhaps because they are more mobile. If targeting strategies differ for urban

\footnotetext{
${ }^{14}$ The magnitude of this effect is driven by the fact that only $1.4 \%$ of the area in which rural people live is zoned for industrial purposes.

${ }^{15}$ Again, the limited degrees of freedom and the high potential for multicollinearity among some regressors lead us to restrict the analysis to those control variables that maximize the predictive power of the model and to those that are interesting from a theoretical perspective.
} 
and rural residents, then the share of county residents who reside in urban areas may impact the overall effectiveness of transfers. For the rural sample, we find that higher shares of urban residency is associated with lower reductions in poverty in Regions I, II, III, IV, V, VI, VII, XII, and XIII. For the urban sample, we find that higher levels of urban residency leads to improved targeting in Regions III, IX, X, XI, and XII. The share of county residents older than age 65 is associated with a higher impact of cash transfers in rural areas (significant at the $99 \%$ confidence level), ${ }^{16}$ but not in urban areas. Again, the point estimate on the share of county residents that requested a CAS-2 Card assessment is negative as anticipated, suggesting that higher eligibility leads to greater reductions in poverty, although this effect is not statistically significant.

Model (2) includes two additional regressors - inequality and the strength of the governing mandate. The effect of inequality is not statistically significant in either case. Finally, the strength of the governing mandate is correlated with larger reductions in poverty among both rural and urban residents, suggesting that members of the coalition of center-left parties and those who are elected by a larger share of the popular vote are more concerned with poverty than with inequality. Still, these effects fall shy of statistical significance, suggesting that public finance has a larger influence than governance in poverty reduction.

\section{Conclusion}

Economic growth in Chile has led to a dramatic reduction in poverty over the past 20 years. A series of cash transfers from the government to poor households has played a crucial role in reducing poverty, but it has had little success in affecting inequality, which remains stubbornly high. Increasingly, the Chilean government has sought to redress both poverty and inequality

\footnotetext{
${ }^{16}$ Again, the magnitude of the point estimate is driven by the relatively low share of elderly people among the rural population in most counties. In entirely rural counties, for example, just under $10 \%$ of the county population is elderly.
} 
through these transfers, and local governments are playing an important part in that effort. Specifically, local governments are charged with evaluating households to identify those most in need of assistance and allocating transfers accordingly. Unfortunately, evaluating the effectiveness of local governments in enacting these policies has been severely restricted by data limitations.

Agostini and Brown (2007a, 2007b) combine census and survey data to provide empirical evidence that cash transfers reduced both poverty and inequality in 2002. However, they also find a significant degree of heterogeneity across counties in terms of the magnitude of these reductions. To better understand such heterogeneity, this paper analyzes how local public finance and the strength of the governing mandate impact reductions in poverty and inequality associated with cash transfers. Identifying these factors will allow policy makers to focus on strengthening specific aspects of local administration and public finance to increase the effectiveness of these social programs.

Our findings show that the local public finance regime has a sizable impact on the efficiency of transfers. For example, a 1-percentage point increase in the share of current expenditures allocated to goods and services increases reductions in inequality resulting from cash transfers by $2.6 \%$, reduces rural inequality by $4.4 \%$, and reduces urban poverty by $1.3 \%$. A 1-percentage point increase in the share of subsidies made available by the regional government that is claimed by the local government increases the reduction in inequality by about $2.6 \%$. Similarly, a 1-percentage point increase in the share of land in the county that is zoned for industrial purposes increases the reduction in inequality stemming from transfers by about $1.6 \%$ and reduces rural poverty by about $1.3 \%$. By contrast, increases in the expenditure/revenue ratio are associated with smaller reductions in inequality from cash transfers and weakly smaller 
reduction in rural poverty. These results are robust to a rich series of controls, including county and socio-demographic characteristics, initial levels of local poverty and inequality, as well as region and urban residence interaction terms.

The results for the strength of the mayor's governing mandate are somewhat weaker: this measure has no statistical effect on inequality, but it does lead to higher reductions in both rural and urban poverty (although the effect is only significant at the $85 \%$ confidence level). This result suggests that members of the Concertación de Partidos por la Democracia and those who received a larger share of the popular vote emphasize poverty rather than inequality in allocating transfers despite increasing pressures from the state to address both.

Our results show that the impact of cash transfers in reducing poverty and inequality is sensitive to the quality of local governments. Therefore, the effectiveness of government transfers could be enhanced not only by increasing the amount transferred, but also by investing in good local government management and by encouraging good governance practices. 


\begin{tabular}{llll}
\multicolumn{2}{l}{ Appendix 1: Counties that are Entirely Rural or Urban } \\
Region & $\mathbf{1 0 0 \%}$ Rural Counties & Region & $\mathbf{1 0 0 \%}$ Urban Counties \\
\hline I & Camiña & V & Viña del Mar \\
I & Colochane & XIII & Santiago \\
I & Huara & XIII & Cerrillos \\
I & Camarones & XIII & Cerro Navia \\
I & General Lagos & XIII & Conchalí \\
II & Sierra Gorda & XIII & El Bosque \\
II & Ollague & XIII & Estación Central \\
III & Alto del Carmen & XIII & Huechuraba \\
IV & Paiguano & XIII & Independencia \\
IV & Río Hurtado & XIII & La Cisterna \\
VI & Pumanque & XIII & La Granja \\
X & Cochamó & XIII & La Pintana \\
X & Curcaco de Vélez & XIII & La Reina \\
X & Puqueldón & XIII & Las Condes \\
X & Palena & XIII & Lo Espejo \\
XI & Lago Verde & XIII & Lo Prado \\
XI & O'Higgins & XIII & Macul \\
XI & Tortel & XIII & Nuñoa \\
XI & Río Iláñez & XIII & Pedro Aguirre Cerda \\
XII & Laguna Blanca & XIII & Peñalolén \\
XII & Río Verde & XIII & Providencia \\
XII & San Gregorio & XIII & Quinta Normal \\
XII & Primavera & XIII & Recoleta \\
XII & Timaukel & XIII & Renca \\
XII & Torres del Paine & XIII & San Joaquín \\
& & XIII & San Miguel \\
& & XIII & San Ramón \\
& & XIII & Vitacura \\
\hline Sorce & & & \\
& & &
\end{tabular}

Source:

SINIM, Undersecretary of Regional Development and Administration, Ministry of the Interior 


\section{References}

ACEMOGLU, D. and ROBINSON, J.A. (2002): "The Political Economy of the Kuznets Curve." Review of Development Economics, Vol. 6, No. 2, pp. 183-203.

AGOSTINI, C.A. and BROWN, P.H. (2007a): "Local Distributional Effects of Government Cash Transfers in Chile," Review of Income and Wealth (forthcoming)

AGOSTINI, C.A. and BROWN, P.H. (2007b): "Cash Transfers and Poverty Reduction in Chile," Documento de Investigación I-187, Ilades-Georgetown.

AHLUWALIA M. (1976): "Income Distribution and Development: Some Stylized Facts.” American Economic Review, Vol. 66, pp. 125-135.

BAKER, J.L. and GROSH, M.E. (1994): "Poverty Reduction through Geographical Targeting: How Well Does It Work?” World Development, Vol. 22, No. 7, pp. 983-95.

BARRO, J. (1999): “Inequality Growth and Investment.” NBER Working Papers No. 7038, National Bureau of Economic Research, Inc.

BIGMAN, D. and FOFACK, H (2000): "Geographical Targeting for Poverty Alleviation: An Introduction to the Special Issue." World Bank Economic Review, Vol. 14, No. 1, pp. $129-45$.

BOURGUIGNON, F. and CHAKRAVARTY, S. (2003): "The Measurement of Multidimensional Poverty.” Journal of Economic Inequality Vol. 1, No. 1, pp. 25-49.

BRADY, D. (2003): "The Politics of Poverty: Left Political Institutions, the Welfare State, and Poverty." Social Forces, Vol. 82, No. 2, pp. 557-588.

CENTRAL INTELLIGENCE AGENCY. (2008): CIA World Factbook. https://www.cia.gov/library/publications/the-world-factbook/ Accessed November 29, 2008.

CHONG, A. and CALDERÓN, C. (2000): "Institutional Quality and Income Distribution" Economic Development and Cultural Change, Vol. 48, No. 4, pp. 761-786.

CHUBB, J. and MOE, T. (1990): Politics, Markets \& America's Schools. Washington D.C.: Brookings.

CONTRERAS, D. (1996): "Pobreza y Desigualdad en Chile: 1987-1992. Discurso, Metodología y Evidencia Empírica." Estudios Públicos, Vol. 64, pp. 57-94.

CONTRERAS, D. (2001): "Economic Growth and Poverty Reduction by Region: Chile 199096."Development Policy Review, Vol. 19, No. 3, pp. 291-302. 
CONTRERAS, D. and RUIZ-TAGLE, J. (1997): "Como Medir la Distribución del Ingreso en Chile." Estudios Públicos Vol. 65, pp. 59-80.

DEMOMBYNES, G., ELBERS, C. LANJOUW, J.O., LANJOUW, P., MISTAEN, J., and ÖZLER, B. (2004): "Producing an Improved Geographic Profile of Poverty: Methodology and Evidence from Three Developing Countries." In Growth, Inequality, and Poverty: Prospects for Pro-Poor Economic Development. Oxford and New York: Oxford University Press, pp. 154-175.

EBERHARTER, V.V. (2001): "Poverty, Inequality, and Poverty Mobility in Germany in the 1990s." Journal of Income Distribution, Vol. 10, No. 1-2, pp. 13-25.

ELBERS, C., LANJOUW, J.O., and LANJOUW, P. (2003): "Micro-Level Estimation of Poverty and Inequality." Econometrica, Vol. 71, No.1.

ELBERS, C., LANJOUW, P.F., MISTAEN, J.A., ÖZLER, B., and SIMLER, K. (2004): "On the Unequal Inequality of Poor Communities." World Bank Economic Review, Vol. 18, No. 2, pp. 401-421.

GREENWOOD, J. and JOVANOVIC, B. (1990): "Financial Development, Growth and Distribution of Income." Journal of Political Economy, No.98.

GUSTAFSSON, B. and JOHANSSON, M. (1999). "In Search of Smoking Guns: What Makes Income Inequality Vary Over Time in Different Countries?” American Sociological Review, vol. 64, pp. 585-605.

GUSTAFSSON, B., LI, S., and SICULAR, T. (2008): Inequality and Public Policy in China. New York: Cambridge University Press.

HAIMOVICH, F., WINKLER, H. and GASPARINI, L. (2006): "Distribución del Ingreso en América Latina: Explorando las Diferencias entre Países" Working Paper No. 34, CEDLAS.

HYMAN, G., LARREA, C. and FARROW, A. (2005): "Methods, Results and Policy Implications of Poverty and Food Security Mapping Assessments." Food Policy, Vol. 30, No. 5-6, pp. 453-460.

JONES, R. (2007): “Income Inequality, Poverty, and Social Spending in Japan.” OECD Economic Department Working Paper Series No. 556, OECD.

KANBUR, R. and ZHANG, X. (2005): "Fifty Years of Regional Inequality in China: A Journey Through Central Planning, Reform and Openness. Review of Development Economics, Vol. 9, No. 1, pp. 87-106.

LENSKI, G. (1966): Power and Privilege: a Theory of Social Stratification. New York. McGraw-Hill. 
NIELSEN, F. and ANDERSON, A. (1995): "Income Inequality, Development and Dualism: Results from an Unbalanced cross National Panel." American Sociological Review, Vol. 60, pp. 674-701.

MAHLER, V. (2002): "Exploring the Subnational Dimension of Income Inequality: An Analysis of the Relationship between Inequality and Electoral Turnout in the Developed Countries.” International Studies Quarterly, Vol. 46, No. 1, pp. 117-142.

PIZZOLITO, G. (2005): "Poverty and Inequality in Chile: Methodological Issues and a Literature Review." Documento de Trabajo No. 20, CEDLAS.

PRESIDENTIAL ADDRESS (2008): “A Better Country with You, More with You.” http://www.emol.com/noticias/documentos/pdfs/discursopresidencial_21demayo20 08.pdf. Accessed October 1, 2008.

RAVALLION, M. (2005): “A Poverty-Inequality Trade Off?” Journal of Economic Inequality, Vol 3., No. 2, pp. 169-181.

SCARPACI, J.L. and IRARRAZAVAL, I. (1994): "Decentralizing a Centralized State: Local Government Finance in Chile Within the Latin American Context." Public Budgeting and Finance, Vol. 14, No. 4, ppl. 120-136.

SIMPSON, M. (1990): "Political Rights and Income Inequality: A Cross-National Test." American Sociological Review, Vol. 55, pp. 682-693.

SOTO, R. and TORCHE, A. (2004): "Spatial Inequality, Growth, and Migration in Chile." Cuadernos de Economía, Vol. 41, pp.401-424.

VAN DER RIJT, J. (2008): “An Alternative Model of the Formation of Political Coalitions." Theory and Decisión, Vol. 64, pp. 81-101.

VON BRAUN, J. (2007): "Rural-Urban Linkages for Growth, Employment, and Poverty Reduction", International Food Policy Research Institute. Ethiopian Economic Association, Fifth International Conference on the Ethiopian Economy, June.

WRATTEN, E. (1995). “Conceptualizing Urban Poverty.” Environment and Urbanization, Vol. 7, No. 1.

ZELLNER, A. (1962): “An Efficient Method of Estimating Seemingly Unrelated Regression Equations and Tests for Aggregation Bias." Journal of the American Statistical Association, Vol. 57, pp. 348-368. 
Table 1: Contemporary Poverty and Inequality Rates in Latin America

\begin{tabular}{lrccc} 
Country & $\begin{array}{c}\text { 2008 Population } \\
\text { (in millions) }\end{array}$ & $\begin{array}{c}\text { 2008 } \\
\text { GDP/Capita }\end{array}$ & $\begin{array}{c}\text { 2008 Headcount } \\
\text { Ratio }\end{array}$ & $\begin{array}{c}\text { 2008 Gini } \\
\text { Coefficient }\end{array}$ \\
\hline Argentina & 40.302 & 15,200 & $23.40 \%$ & 0.49 \\
Bolivia & 9.248 & 4,000 & $60.00 \%$ & 0.59 \\
Brazil & 190.011 & 8,800 & $31.00 \%$ & 0.57 \\
Chile & 16.285 & 12,600 & $13.70 \%$ & 0.54 \\
Colombia & 44.380 & 8,600 & $49.20 \%$ & 0.54 \\
Costa Rica & 4.196 & 10,300 & $16.00 \%$ & 0.50 \\
Ecuador & 13.928 & 7,200 & $38.30 \%$ & 0.46 \\
Guatemala & 13.002 & 4,700 & $56.20 \%$ & 0.55 \\
Honduras & 7.484 & 3,100 & $50.70 \%$ & 0.54 \\
Mexico & 108.701 & 10,700 & $17.60 \%$ & 0.51 \\
Nicaragua & 5.675 & 3,100 & $48.00 \%$ & 0.43 \\
Paraguay & 6.831 & 4,500 & $32.00 \%$ & 0.57 \\
Peru & 29.181 & 7,800 & $44.50 \%$ & 0.52 \\
Uruguay & 3.478 & 11,600 & $27.40 \%$ & 0.45 \\
Venezuela & 26.415 & 12,200 & $37.90 \%$ & 0.48 \\
\hline Sourc:Centray
\end{tabular}

Source: Central Intelligence Agency (2008)

Notes:

Incomes are reported in PPP equivalent US dollars 
Table 2: County-Level Changes in Gini Coefficients and Headcount Ratios

\begin{tabular}{|c|c|c|c|c|c|c|c|}
\hline & Variable & $\mathbf{N}$ & Mean & $\begin{array}{c}\text { Weighted } \\
\text { Mean }\end{array}$ & Std. Dev. & Max. & Min. \\
\hline \multicolumn{8}{|l|}{ National } \\
\hline & $\% \Delta$ Gini & 341 & $-7.71 \%$ & & 0.0368 & $-19.5 \%$ & $-0.3 \%$ \\
\hline & $\% \Delta \mathrm{HCR}$ & 341 & $-13.53 \%$ & & 0.0583 & $-40.4 \%$ & $-4.9 \%$ \\
\hline & $\% \Delta$ Rural HCR & 312 & $-23.45 \%$ & & 0.0519 & $-44.7 \%$ & $-12.6 \%$ \\
\hline & $\% \Delta$ Urban HCR & 315 & $-8.17 \%$ & & 0.0162 & $-12.3 \%$ & $-4.1 \%$ \\
\hline \multicolumn{8}{|l|}{ Region } \\
\hline \multirow{4}{*}{ - } & $\% \Delta$ Gini & 10 & $-6.24 \%$ & $-5.34 \%$ & 0.0074 & $-7.51 \%$ & $-4.89 \%$ \\
\hline & $\% \Delta \mathrm{HCR}$ & 10 & $-15.80 \%$ & $-9.67 \%$ & 0.0519 & $-23.34 \%$ & $-8.67 \%$ \\
\hline & $\% \Delta$ Rural HCR & 10 & $-22.61 \%$ & $-22.34 \%$ & 0.0469 & $-34.43 \%$ & $-16.73 \%$ \\
\hline & $\% \Delta$ Urban HCR & 5 & $-8.21 \%$ & $-8.74 \%$ & 0.0056 & $-8.99 \%$ & $-7.60 \%$ \\
\hline \multirow{4}{*}{ II } & $\% \Delta$ Gini & 9 & $-3.09 \%$ & $-3.12 \%$ & 0.0020 & $-3.50 \%$ & $-2.72 \%$ \\
\hline & $\% \Delta \mathrm{HCR}$ & 9 & $-11.82 \%$ & $-6.00 \%$ & 0.0908 & $-27.44 \%$ & $-5.40 \%$ \\
\hline & $\% \Delta$ Rural HCR & 9 & $-30.28 \%$ & $-28.62 \%$ & 0.0584 & $-44.68 \%$ & $-25.06 \%$ \\
\hline & $\% \Delta$ Urban HCR & 7 & $-5.61 \%$ & $-5.63 \%$ & 0.0063 & $-6.67 \%$ & $-4.79 \%$ \\
\hline \multirow{4}{*}{ III } & $\% \Delta$ Gini & 9 & $-6.49 \%$ & $-6.30 \%$ & 0.0050 & $-7.37 \%$ & $-5.69 \%$ \\
\hline & $\% \Delta \mathrm{HCR}$ & 9 & $-13.26 \%$ & $-10.58 \%$ & 0.0680 & $-30.73 \%$ & $-8.91 \%$ \\
\hline & $\% \Delta$ Rural HCR & 9 & $-34.56 \%$ & $-33.25 \%$ & 0.0515 & $-44.64 \%$ & $-29.08 \%$ \\
\hline & $\% \Delta$ Urban HCR & 8 & $-8.70 \%$ & $-8.93 \%$ & 0.0063 & $-9.37 \%$ & $-7.62 \%$ \\
\hline \multirow{4}{*}{ IV } & $\% \Delta$ Gini & 15 & $-7.00 \%$ & $-6.45 \%$ & 0.0059 & $-7.99 \%$ & $-5.84 \%$ \\
\hline & $\% \Delta \mathrm{HCR}$ & 15 & $-14.77 \%$ & $-10.94 \%$ & 0.0505 & $-24.16 \%$ & $-8.51 \%$ \\
\hline & $\% \Delta$ Rural HCR & 15 & $-23.09 \%$ & $-22.48 \%$ & 0.0095 & $-25.44 \%$ & $-21.83 \%$ \\
\hline & $\% \Delta$ Urban HCR & 13 & $-7.33 \%$ & $-7.63 \%$ & 0.0056 & $-8.10 \%$ & $-6.42 \%$ \\
\hline \multirow{4}{*}{ V } & $\% \Delta$ Gini & 38 & $-4.61 \%$ & $-4.33 \%$ & 0.0090 & $-6.55 \%$ & $-2.34 \%$ \\
\hline & $\% \Delta \mathrm{HCR}$ & 38 & $-9.36 \%$ & $-8.26 \%$ & 0.0196 & $-13.92 \%$ & $-7.16 \%$ \\
\hline & $\% \Delta$ Rural HCR & 36 & $-22.81 \%$ & $-22.83 \%$ & 0.0176 & $-29.39 \%$ & $-20.39 \%$ \\
\hline & $\% \Delta$ Urban HCR & 38 & $-7.12 \%$ & $-7.35 \%$ & 0.0045 & $-8.17 \%$ & $-6.30 \%$ \\
\hline \multirow{4}{*}{ VI } & $\% \Delta$ Gini & 33 & $-7.16 \%$ & $-6.55 \%$ & 0.0234 & $-19.46 \%$ & $-4.67 \%$ \\
\hline & $\% \Delta \mathrm{HCR}$ & 33 & $-11.87 \%$ & $-9.90 \%$ & 0.0320 & $-21.18 \%$ & $-7.15 \%$ \\
\hline & $\% \Delta$ Rural HCR & 33 & $-19.64 \%$ & $-19.37 \%$ & 0.0157 & $-23.19 \%$ & $-15.97 \%$ \\
\hline & $\% \Delta$ Urban HCR & 32 & $-6.71 \%$ & $-6.77 \%$ & 0.0060 & $-8.22 \%$ & $-5.47 \%$ \\
\hline \multirow{4}{*}{ VII } & $\% \Delta$ Gini & 30 & $-9.25 \%$ & $-8.68 \%$ & 0.0099 & $-11.26 \%$ & $-7.23 \%$ \\
\hline & $\% \Delta \mathrm{HCR}$ & 30 & $-14.38 \%$ & $-12.12 \%$ & 0.0306 & $-18.74 \%$ & $-8.66 \%$ \\
\hline & $\% \Delta$ Rural HCR & 30 & $-22.00 \%$ & $-21.91 \%$ & 0.0105 & $-24.52 \%$ & $-20.53 \%$ \\
\hline & $\% \Delta$ Urban HCR & 30 & $-8.35 \%$ & $-8.35 \%$ & 0.0075 & $-9.66 \%$ & $-6.21 \%$ \\
\hline \multirow{4}{*}{ VIII } & $\% \Delta$ Gini & 52 & $-10.01 \%$ & $-8.82 \%$ & 0.0178 & $-12.74 \%$ & $-5.14 \%$ \\
\hline & $\% \Delta \mathrm{HCR}$ & 52 & $-14.25 \%$ & $-12.50 \%$ & 0.0304 & $-21.60 \%$ & $-8.39 \%$ \\
\hline & $\% \Delta$ Rural HCR & 52 & $-22.25 \%$ & $-22.10 \%$ & 0.0177 & $-25.69 \%$ & $-16.30 \%$ \\
\hline & $\% \Delta$ Urban HCR & 52 & $-9.23 \%$ & $-9.87 \%$ & 0.0099 & $-11.74 \%$ & $-6.87 \%$ \\
\hline \multirow{4}{*}{ IX } & $\% \Delta$ Gini & 31 & $-12.92 \%$ & $-11.66 \%$ & 0.0166 & $-15.46 \%$ & $-9.18 \%$ \\
\hline & $\% \Delta \mathrm{HCR}$ & 31 & $-14.85 \%$ & $-13.28 \%$ & 0.0231 & $-18.84 \%$ & $-10.17 \%$ \\
\hline & $\% \Delta$ Rural HCR & 31 & $-23.26 \%$ & $-22.63 \%$ & 0.0246 & $-27.30 \%$ & $-18.82 \%$ \\
\hline & $\% \Delta$ Urban HCR & 31 & $-8.50 \%$ & $-8.89 \%$ & 0.0055 & $-9.70 \%$ & $-7.34 \%$ \\
\hline
\end{tabular}




\begin{tabular}{|c|c|c|c|c|c|c|c|}
\hline \multirow{4}{*}{$\mathrm{X}$} & $\% \Delta$ Gini & 42 & $-11.54 \%$ & $-10.04 \%$ & 0.0157 & $-14.44 \%$ & $-7.34 \%$ \\
\hline & $\% \Delta \mathrm{HCR}$ & 42 & $-18.49 \%$ & $-15.58 \%$ & 0.0427 & $-29.97 \%$ & $-9.46 \%$ \\
\hline & $\% \Delta$ Rural HCR & 42 & $-27.52 \%$ & $-27.73 \%$ & 0.0207 & $-33.02 \%$ & $-21.72 \%$ \\
\hline & $\% \Delta$ Urban HCR & 38 & $-10.28 \%$ & $-10.77 \%$ & 0.0073 & $-11.70 \%$ & $-8.60 \%$ \\
\hline \multirow{4}{*}{ XI } & $\% \Delta$ Gini & 10 & $-10.54 \%$ & $-9.51 \%$ & 0.0116 & $-12.29 \%$ & $-8.66 \%$ \\
\hline & $\% \Delta \mathrm{HCR}$ & 10 & $-25.59 \%$ & $-16.75 \%$ & 0.1134 & $-40.40 \%$ & $-13.63 \%$ \\
\hline & $\% \Delta$ Rural HCR & 10 & $-37.32 \%$ & $-37.83 \%$ & 0.0233 & $-40.40 \%$ & $-32.88 \%$ \\
\hline & $\% \Delta$ Urban HCR & 6 & $-11.92 \%$ & $-11.64 \%$ & 0.0037 & $-12.32 \%$ & $-11.36 \%$ \\
\hline \multirow{4}{*}{ XII } & $\% \Delta$ Gini & 10 & $-1.98 \%$ & $-2.92 \%$ & 0.0123 & $-4.02 \%$ & $-0.25 \%$ \\
\hline & $\% \Delta \mathrm{HCR}$ & 10 & $-20.04 \%$ & $-10.75 \%$ & 0.0920 & $-30.65 \%$ & $-8.67 \%$ \\
\hline & $\% \Delta$ Rural HCR & 10 & $-24.90 \%$ & $-20.07 \%$ & 0.0493 & $-30.65 \%$ & $-16.92 \%$ \\
\hline & $\% \Delta$ Urban HCR & 4 & $-9.78 \%$ & $-10.23 \%$ & 0.0160 & $-11.58 \%$ & $-7.93 \%$ \\
\hline \multirow{4}{*}{ XIII } & $\% \Delta$ Gini & 52 & $-2.99 \%$ & $-2.94 \%$ & 0.0029 & $-3.64 \%$ & $-2.37 \%$ \\
\hline & $\% \Delta \mathrm{HCR}$ & 52 & $-7.60 \%$ & $-7.02 \%$ & 0.0203 & $-16.33 \%$ & $-4.86 \%$ \\
\hline & $\% \Delta$ Rural HCR & 25 & $-14.97 \%$ & $-15.64 \%$ & 0.0164 & $-20.16 \%$ & $-12.55 \%$ \\
\hline & $\% \Delta$ Urban HCR & 51 & $-6.83 \%$ & $-6.86 \%$ & 0.0148 & $-11.41 \%$ & $-4.14 \%$ \\
\hline
\end{tabular}

Sources:

County-level changes in Gini Coefficients: Agostini and Brown (2007a)

County-level changes in Headcount Ratios: Agostini and Brown (2007b) 
Table 3: Descriptive Statistics of Explanatory Variables: Total Sample

Std.

\begin{tabular}{|c|c|c|c|}
\hline Variable & Explanation & Mean & Dev. \\
\hline \multicolumn{4}{|l|}{ Public Finance } \\
\hline G\&S / Expenditures ${ }^{\mathrm{A}}$ & $\begin{array}{l}\text { Current expenditures on goods and } \\
\text { services / current expenditures }\end{array}$ & $18.2 \%$ & 0.075 \\
\hline Expenditure/Revenue ${ }^{\mathrm{A}}$ & $\begin{array}{l}\text { Current expenditures / current } \\
\text { revenues }\end{array}$ & $82.9 \%$ & 0.188 \\
\hline Fraction of Subsidies & Share of water subsidies authorized & & \\
\hline Claimed $^{\mathrm{A}}$ & $\begin{array}{l}\text { by the regional government claimed } \\
\text { by the county government }\end{array}$ & $78.6 \%$ & 0.157 \\
\hline$\%$ Industrial Zoning ${ }^{\mathrm{A}}$ & $\begin{array}{l}\text { Share of county land designated for } \\
\text { industrial purposes }\end{array}$ & $7.8 \%$ & 0.233 \\
\hline \multicolumn{4}{|l|}{ Governance } \\
\hline Strength of Governing & $\%$ of votes won by the mayor in & & \\
\hline Mandate $^{\mathrm{B}}$ & $\begin{array}{l}2002 \text { if the mayor belongs to the } \\
\text { ruling coalition }\end{array}$ & $18.2 \%$ & $19.4 \%$ \\
\hline \multicolumn{4}{|c|}{ County and Socio-Demographic Characteristics } \\
\hline Ease of Access ${ }^{\mathrm{A}}$ & $\begin{array}{l}\text { Dummy, }=1 \text { if regional capital is } \\
\text { accessible by sealed roads }\end{array}$ & 0.82 & 0.39 \\
\hline Average Education $^{\mathrm{A}}$ & Average years among $15+$ group & 7.42 & 1.23 \\
\hline$\%$ Urban Population $^{\mathrm{A}}$ & Share of county population & $61.0 \%$ & 0.303 \\
\hline$\%$ Coverage of CAS- 2 Card $^{\mathrm{A}}$ & $\begin{array}{l}\text { Share of county residents that } \\
\text { requested poverty assistance }\end{array}$ & $52.1 \%$ & 0.220 \\
\hline $\begin{array}{l}\% \text { of Households with Public } \\
\text { Water Supply }{ }^{\mathrm{C}}\end{array}$ & Share of total households in county & $76.0 \%$ & 0.214 \\
\hline $\begin{array}{l}\% \text { of Households with a } \\
\text { Female Head }{ }^{\mathrm{C}}\end{array}$ & Share of total households in county & $28.1 \%$ & 0.052 \\
\hline$\%$ of Elderly in Household ${ }^{\mathrm{C}}$ & $\begin{array}{l}\text { Share of county population aged } \\
65+\end{array}$ & $8.9 \%$ & 0.023 \\
\hline
\end{tabular}

Sources:

A SINIM, Undersecretary of Regional Development and Administration, Ministry of the Interior

B Electoral Service

C 2002 Census of Population and Housing, National Institute of Statistics

Authors' Calculations 
Table 4: Changes in Inequality (Ordinary Least Squares)

\begin{tabular}{|c|c|c|c|}
\hline Dependent Variable: $\Delta \%$ Gini & (1) & (2) & (3) \\
\hline \multirow[t]{2}{*}{ G\&S / Expenditures } & -0.0247 & -0.0224 & $-0.0258 *$ \\
\hline & $(0.0161)$ & $(0.0146)$ & $(0.0148)$ \\
\hline \multirow[t]{2}{*}{ Expenditure/Revenue } & $0.0091 *$ & $0.008 *$ & $0.0107^{*}$ \\
\hline & $(0.0048)$ & $(0.0046)$ & $(0.0059)$ \\
\hline \multirow[t]{2}{*}{ Fraction of Subsidies Claimed } & $-0.0279 * * *$ & $-0.0257 * * *$ & $-0.0257 * * *$ \\
\hline & $(0.0083)$ & $(0.0081)$ & $(0.0086)$ \\
\hline \multirow[t]{2}{*}{$\%$ Industrial Zoning } & $-0.0149 * * *$ & $-0.0159 * * *$ & $-0.0168 * * *$ \\
\hline & $(0.0045)$ & $(0.0039)$ & $(0.0047)$ \\
\hline \multirow[t]{2}{*}{ Strength of Governing Mandate } & & & 0.0059 \\
\hline & & & $(0.0041)$ \\
\hline \multirow[t]{2}{*}{ Ease of Access } & $0.0079 * * *$ & $0.0093 * * *$ & $0.0089 * * *$ \\
\hline & $(0.0030)$ & $(0.0031)$ & $(0.0029)$ \\
\hline \multirow[t]{2}{*}{ Average Schooling } & $0.0051 * * *$ & 0.0029 & 0.0031 \\
\hline & $(0.0017)$ & $(0.0026)$ & $(0.0031)$ \\
\hline \multirow[t]{2}{*}{$\%$ Urban Population } & $0.0383 * * *$ & $0.0431 * * *$ & $0.0431 * * *$ \\
\hline & $(0.012)$ & $(0.0101)$ & $(0.0124)$ \\
\hline \multirow[t]{2}{*}{$\%$ Coverage of CAS- 2 Card } & -0.0078 & -0.0068 & -0.0069 \\
\hline & $(0.0057)$ & $(0.0056)$ & $(0.0052)$ \\
\hline \multirow[t]{2}{*}{$\%$ of Households with a Female Head } & $0.066 *$ & $0.0712 * *$ & $0.0691 * *$ \\
\hline & $(0.0341)$ & $(0.0318)$ & $(0.0351)$ \\
\hline \multirow[t]{2}{*}{$\%$ of Households with Public Water Supply } & $0.0442 * * *$ & $0.0399 * * *$ & $0.0388 * * *$ \\
\hline & $(0.0148)$ & $(0.0129)$ & $(0.0133)$ \\
\hline \multirow[t]{2}{*}{ HCR Before Transfers } & & -0.0348 & -0.0353 \\
\hline & & $(0.0313)$ & $(0.0331)$ \\
\hline \multirow[t]{2}{*}{ Region I x Urban } & $-0.0291 * * *$ & $-0.0271 * * *$ & $-0.0265 * * *$ \\
\hline & $(0.0071)$ & $(0.0083)$ & $(0.0088)$ \\
\hline \multirow[t]{2}{*}{ Region II x Urban } & -0.0049 & -0.0059 & -0.0064 \\
\hline & $(0.0086)$ & $(0.0061)$ & $(0.0099)$ \\
\hline \multirow[t]{2}{*}{ Region III x Urban } & $-0.0434 * * *$ & $-0.0412 * * *$ & $-0.0418 * * *$ \\
\hline & $(0.0053)$ & $(0.0041)$ & $(0.0055)$ \\
\hline \multirow[t]{2}{*}{ Region IV x Urban } & $-0.0339 * * *$ & $-0.0309 * * *$ & $-0.0308 * * *$ \\
\hline & $(0.0061)$ & $(0.0058)$ & $(0.0056)$ \\
\hline \multirow[t]{2}{*}{ Region V x Urban } & $-0.0128 * * *$ & $-0.0111 * * *$ & $-0.0118 * *$ \\
\hline & $(0.0044)$ & $(0.0033)$ & $(0.0048)$ \\
\hline \multirow[t]{2}{*}{ Region VI x Urban } & $-0.0348 * * *$ & $-0.0358 * * *$ & $-0.0361 * * *$ \\
\hline & $(0.0046)$ & $(0.0042)$ & $(0.0051)$ \\
\hline \multirow[t]{2}{*}{ Region VII x Urban } & $-0.0584 * * *$ & $-0.0559 * * *$ & $-0.0573 * * *$ \\
\hline & $(0.0037)$ & $(0.0048)$ & $(0.0051)$ \\
\hline \multirow[t]{2}{*}{ Region VIII x Urban } & $-0.0621 * * *$ & $-0.0555 * * *$ & $-0.0552 * * *$ \\
\hline & $(0.0051)$ & $(0.0063)$ & $(0.0071)$ \\
\hline Region IX x Urban & $-.0976 * * *$ & $-0.0929 * * *$ & $-0.0889 * * *$ \\
\hline & $(0.0081)$ & $(0.0089)$ & $(0.0098)$ \\
\hline Region X x Urban & $-0.0687 * * *$ & $-0.0701 * * *$ & $-0.0679 * * *$ \\
\hline & $(0.0048)$ & $(0.0058)$ & $(0.0053)$ \\
\hline Region XI x Urban & $-0.0611 * * *$ & $-0.0614 * * *$ & $-0.0622 * * *$ \\
\hline & $(0.0059)$ & $(0.0091)$ & $(0.0094)$ \\
\hline Region XII x Urban & 0.0079 & 0.0081 & 0.0072 \\
\hline & $(0.0131)$ & $(0.0129)$ & $(0.0146)$ \\
\hline Constant & $-0.1489 * * *$ & $-0.1331 * * *$ & $-0.1226 * * *$ \\
\hline & $(0.0114)$ & $(0.0258)$ & $(0.0259)$ \\
\hline $\mathrm{N}$ & 327 & 327 & 327 \\
\hline R-Squared & 0.8219 & 0.8221 & 0.8323 \\
\hline Wald Test (Chi2) & 3008 & 2847 & 3098 \\
\hline Prob $>$ chi 2 & 0.00 & 0.00 & 0.00 \\
\hline
\end{tabular}


Table 5: Changes in Poverty Rates (Seemingly Unrelated Regression)

\begin{tabular}{|c|c|c|c|c|}
\hline \multirow[b]{2}{*}{ Dependent Variable : $\Delta \mathrm{HC}$} & \multicolumn{2}{|c|}{ Rural } & \multicolumn{2}{|c|}{ Urban } \\
\hline & (1) & (2) & (1) & (2) \\
\hline \multirow[t]{2}{*}{ G\&S / Expenditures } & $-0.0436 * *$ & $-0.0437 * *$ & $-0.0129 *$ & -0.0123 \\
\hline & $(0.022)$ & $(0.022)$ & $(0.0078)$ & $(0.0079)$ \\
\hline \multirow[t]{2}{*}{ Expenditure/Revenue } & 0.0090 & 0.0090 & 0.0070 & 0.0070 \\
\hline & $(0.0061)$ & $(0.0065)$ & $(0.0075)$ & $(0.0078)$ \\
\hline \multirow[t]{2}{*}{ Fraction of Subsidies Claimed } & 0.00040 & 0.00050 & 0.00060 & 0.00060 \\
\hline & $(0.0101)$ & $(0.0095)$ & $(0.0103)$ & $(0.0108)$ \\
\hline \multirow{2}{*}{$\%$ Industrial Zoning } & $-0.125 * * *$ & $-0.123 * * *$ & -0.0091 & -0.0122 \\
\hline & $(0.0111)$ & $(0.0114)$ & $(0.0121)$ & $(0.0184)$ \\
\hline \multirow[t]{2}{*}{ Strength of Governing Mandate } & & -0.0053 & & -0.0027 \\
\hline & & $(0.0036)$ & & $(0.0018)$ \\
\hline \multirow[t]{2}{*}{ Ease of Access } & 0.0050 & 0.0040 & $0.0061 * * *$ & $0.0054 * * *$ \\
\hline & $(0.0034)$ & $(0.0040)$ & $(0.0014)$ & $(0.0014)$ \\
\hline \multirow[t]{2}{*}{ \% Urban Population } & $0.0737 * * *$ & $0.0741^{* * *}$ & $0.0087^{* *}$ & $0.0092 *$ \\
\hline & $(0.0103)$ & $(0.0108)$ & $(0.0041)$ & $(0.0053)$ \\
\hline \multirow[t]{2}{*}{$\%$ Coverage of CAS- 2 Card } & $0.0095 * * *$ & $0.0096 * * *$ & 0.0059 & 0.0058 \\
\hline & $(0.0029)$ & $(0.0032)$ & $(0.0081)$ & $(0.0078)$ \\
\hline \multirow{2}{*}{$\%$ of Elderly in Household } & $-0.314 * * *$ & $-0.315 * *$ & 0.022 & 0.014 \\
\hline & $(0.103)$ & $(0.142)$ & $(0.039)$ & $(0.043)$ \\
\hline \multirow[t]{2}{*}{ Gini Before Transfers } & & 0.0031 & & -0.039 \\
\hline & & $(0.0775)$ & & $(0.0381)$ \\
\hline \multirow[t]{2}{*}{ Region I x Urban } & $-0.0306^{*}$ & $-0.0308 * *$ & $-0.0221 * * *$ & $-0.0231 * * *$ \\
\hline & $(0.0163)$ & $(0.0149)$ & $(0.0049)$ & $(0.0051)$ \\
\hline \multirow[t]{2}{*}{ Region II x Urban } & -0.002 & -0.0047 & $0.0129 * * *$ & $0.0127 * * *$ \\
\hline & $(0.0082)$ & $(0.008)$ & $(0.0043)$ & $(0.0039)$ \\
\hline \multirow[t]{2}{*}{ Region III x Urban } & $-0.0400 * * *$ & $-.0397 * * *$ & $-0.2488 * * *$ & $-0.2417 * * *$ \\
\hline & $(0.0082)$ & $(0.0074)$ & $(0.0046)$ & $(0.0041)$ \\
\hline \multirow[t]{2}{*}{ Region IV x Urban } & $-0.0166^{*}$ & -0.015 & $-0.009 * *$ & $-0.011 * * *$ \\
\hline & $(0.0099)$ & $(0.0097)$ & $(0.0041)$ & $(0.0038)$ \\
\hline \multirow[t]{2}{*}{ Region V x Urban } & $-0.0168 * * *$ & $-0.0204 * * *$ & -0.0048 & -0.0044 \\
\hline & $(0.0064)$ & $(0.0073)$ & $(0.0039)$ & $(0.0028)$ \\
\hline \multirow[t]{2}{*}{ Region VI x Urban } & -0.00063 & -0.0025 & $0.0056^{*}$ & $0.0067^{* *}$ \\
\hline & $(0.0085)$ & $(0.0081)$ & $(0.0034)$ & $(0.0033)$ \\
\hline \multirow[t]{2}{*}{ Region VII x Urban } & $-0.0298 * * *$ & $-0.0258 * *$ & $-0.0258 * * *$ & $-0.0253^{* * *}$ \\
\hline & $(0.0092)$ & $(0.0098)$ & $(0.0027)$ & $(0.0032)$ \\
\hline \multirow[t]{2}{*}{ Region VIII x Urban } & $-0.059 * * *$ & $-0.0548 * * *$ & $-0.0372 * * *$ & $-0.0319 * * *$ \\
\hline & $(0.0073)$ & $(0.0084)$ & $(0.0025)$ & $(0.0021)$ \\
\hline Region IX x Urban & $-0.0503 * * *$ & $-0.0415 * * *$ & $-0.2396 * * *$ & $-0.2435^{* * *}$ \\
\hline & $(0.0084)$ & $(0.0139)$ & $(0.0042)$ & $(0.0045)$ \\
\hline Region X x Urban & $-0.0727 * * *$ & $-0.068 * * *$ & $-0.0597 * * *$ & $-0.0562 * * *$ \\
\hline & $(0.0094)$ & $(0.0106)$ & $(0.0041)$ & $(0.0047)$ \\
\hline Region XI x Urban & $-0.0897 * * *$ & $-0.0824 * * *$ & $-0.0657 * * *$ & $-0.0653 * * *$ \\
\hline & $(0.0117)$ & $(0.0144)$ & $(0.0066)$ & $(0.0068)$ \\
\hline Region XII x Urban & -0.0241 & -0.0222 & $-0.3014 * * *$ & $-0.3111 * * *$ \\
\hline & $(0.0149)$ & $(0.0145)$ & $(0.0053)$ & $(0.0051)$ \\
\hline Constant & -0.186 & -0.178 & -0.0889 & -0.0745 \\
\hline & $(0.0121)$ & $(0.0382)$ & $(0.0047)$ & $(0.0158)$ \\
\hline $\mathrm{N}$ & 299 & 299 & 301 & 301 \\
\hline R-Squared & 0.8015 & 0.8013 & 0.7723 & 0.7731 \\
\hline Wald Test & 1110.19 & 1111.17 & 981.53 & 992.12 \\
\hline Prob $>$ Chi2 & 0.00 & 0.00 & 0.00 & 0.00 \\
\hline
\end{tabular}

Notes:

Standard errors are in parentheses.

The Breush-Pagan test aims to verify whether the covariance matrix of the errors is diagonal. Test results of the SUR model of Equation (2) are presented to reject the hypothesis that the mistakes of the equations in the model are not correlated.

*Significant at the 5\% level; ** Significant at the $1 \%$ level; *** Significant at the $0.1 \%$ level 